\title{
Rh Titer Measurement
}

National Cancer Institute

\section{Source}

National Cancer Institute. Rh Titer Measurement. NCI Thesaurus. Code C99052.

An immunology test that detects the quantity of anti-Rhesus antibodies in the serum of a pregnant woman. 